\title{
PENGARUH KUALITAS PELAYANAN TERHADAP KEPUASAN PELANGGAN DALAM MENGGUNAKAN LISTRIK PRABAYAR PADA PT. PLN (PERSERO) RAYON SEKAYU
}

\author{
SRI GUSTINI \\ srigustini.mudrik@gmail.com \\ HERIYANA \\ JUANDA
}

\begin{abstract}
ABSTRAK
PT. PLN (Persero) Rayon Sekayu merupakan suatu perusahaan yang bergerak dalam bidang ketenagalistrikan. Salah satu jasa yang ditawarkan oleh perusahaan ialah pelayanan pembayaran rekening listrik, pelayanan pemasangan baru dan perubahan daya, pelayanan keluhan pelanggan mengenai pembacaan meter dan sebagainya. Tujuan penelitian yang dilakukan adalah untuk mengetahui pengaruh kualitas pelayanan terhadap kepuasan pelanggan listrik prabayar pada PT. PLN (Persero) Rayon Sekayu. Metode penelitian yang digunakan penulis metode deskriptif kuantitatif. Teknik pengumpulan data yang digunakan adalah kuesioner, observasi dan studi dokumentasi. Analisis data dilakukan menggunakan uji validitas, uji reliabilitas, regresi linier sederhana, koefisien korelasi dan uji hipotesis (uji t) dengan Mengunakan SPSS 22. Hasil penelitian menunjukkan bahwa variabel kualitas pelayanan mempunyai hubungan positif yang tidak terlalu kuat dan mempengaruhi kepuasan pelanggan pada PT. PLN (Persero) Rayon Sekayu
\end{abstract}

Kata Kunci : Kualitas Layanan, Kepuasan Pelanggan

\section{LATAR BELAKANG}

Persaingan global merupakan fenomena yang tidak dapat dihindarkan dalam dunia industri yang ditandai dengan perubahan-perubahan yang serba cepat dibidang komunikasi, informasi dan teknologi, sehingga menuntut perusahaan untuk meningkatkan pelayanan secara profesional sesuai dengan bidangnya masing-masing. Perubahan teknologi dan arus informasi yang sangat cepat telah mendorong perusahaan untuk menghasilkan produk yang dapat memenuhi kebutuhan dan keinginan konsumen, sehingga konsumen merasa puas dengan apa yang telah mereka dapatkan dari perusahaan. Berbagai upaya yang telah dilakukan perusahaan dalam memenuhi kebutuhan dan keinginan konsumen, salah satunya dengan memberikan kesan atau citra yang baik dalam hal produk baik barang maupun jasa.

Pelayanan merupakan suatu bentuk kegiatan sosial untuk membantu orang lain dan mempunyai tujuan membangun kerja sama antar pihak dalam jangka panjang dengan prinsip saling menguntungkan antar pihak terkait. Pelayanan yang bagus adalah pelayanan yang dapat memahami keinginan dan kebutuhan konsumen serta berusaha untuk memberikan nilai lebih kepada pelanggan.

Kualitas pelayanan dapat didefinisikan yaitu seberapa jauh perbedaan antara kenyataan dan harapan pelanggan antara layananyang mereka terima atau peroleh. Perusahaan harus menempatkan orientasi pada kualitas pelayanan dan kepuasan pelanggan sebagai tujuan utama. Hal ini tercermin dari semakin banyaknya perusahaan yang menyertakan komitmennya terhadap pelayanan dalam pernyataan misinya, iklan, maupun public relationsrelease. Kunci utama perusahaan untuk memenangkan persaingan adalah memberikan nilai dan kepuasan kepada pelanggan melalui penyampaian produk dan jasa yang berkualitas dengan harga yang bersaing, (Kotler, 2011: 103).

Kualitas memiliki hubungan yang erat dengan kepuasan konsumen. Kualitas memberikan suatu dorongan kepada konsumen untuk menjalin ikatan hubungan yang kuat dengan institusi jasa. Dalam jangka panjang, ikatan seperti ini memungkinkan sebuah institusi jasa untuk memahami dengan seksama harapan konsumen serta kebutuhan mereka. Pelayanan yang bermutu dapat diidentifikasi melalui kepuasan konsumen, khususnya adalah pelanggan, (Tjiptono, 2011: 54)

Kepuasan pelanggan adalah evaluasi pembeli dimana alternatif yang di pilih sekurangkurangnya sama atau melampaui harapan pelanggan. Sedangkan ketidakpuasan timbul apabila hasil (Outcome) tidak memenuhi harapan, (Kotler (2011: 74). 
PT. PLN (Persero) Rayon Sekayu merupakan Ranting dibawah PLN Area Palembang. PT. PLN (Persero) Rayon Sekayu yang melayani pelanggan dengan daerah distribusi yakni Kecamatan Sekayu, Sanga Desa, Keluang, Babat Toman, Lawang Wetan, Sungai Keruh, Jirak. Lokasi PT. PLN (Persero) Rayon Sekayu memiliki tempat dan kedudukan yang strategis yaitu berada di Jalan Kopral Hanafiah No.221 Sekayu Kabupaten Musi Banyuasin. Lokasi ini strategis karena berada dipinggir jalan dan terletak didekat kantor Pemerintahan Daerah Kabupaten Musi Banyuasin disehingga memudahkan para pelanggan yang ada di daerah Sekayu dan sekitarnya untuk bisa memakai jasa listrik dari PT. PLN (Persero) Rayon Sekayu.

Berdasarkan hasil pengamatan peneliti dilapangan bahwa pelayanan PT. PLN (Persero) Rayon Sekayu telah memberikan pelayanan yang cepat tanggap terhadap keluhan pelanggan dan memberikan informasi yang akurat. Dengan adanya penarikan subsidi dari pemerintah sehingga tarif listrik mengalami kenaikan signifikan dan menyebabkan banyak pelanggan yang merasa terlalu mahal pembayaran listriknya karna tagihan listrik tidak sesuai dengan apa yang mereka pakai, kualitas meteran yang kurang baik yang menyebabkan sering mengalami kerusakanseperti pada mesin LPB yang sulit diisi token (pulsa listrik) meteran yang sering error dan harus minta clear tamper yang waktunya terlalu lama, sehingga membutuhkan waktu untuk menggantinya,belum adanya loket untuk pembelian token listrik pada daerah tertentu dan pemeliharaan jaringan listrik yang belum maksimal sehingga sering terjadi mati lampu. Dengan kejadian tersebut pelanggan PT. PLN (Persero) Rayon Sekayu merasa tidak puas.

Berdasarkan uraian di atas, maka penulis tertarik untuk melakukan penelitian dengan judul : "Pengaruh Kualitas Pelayanan Terhadap Kepuasan Pelanggan Dalam Menggunakan Listrik Prabayar pada PT. PLN (Persero) Rayon Sekayu”.

\section{KAJIAN PUSTAKA}

\section{Kualitas Pelayanan}

Menurut Tjiptono (2011: 21), definisi kualitas pelayanan adalah upaya pemenuhan kebutuhan yang dibarengi dengan keinginan konsumen serta ketepatan cara penyampaiannya agar dapat memenuhi harapan dan kepuasan pelanggan tersebut. Sedangkan Kotler (2011: 146), kualitas pelayanan adalah kegiatan atau manfaat yang dapat diberikan oleh suatu pihak kepada pihak lain yang pada dasarnya tidak terwujud dan tidak pula berakibat pemilihan sesuatu.

Berdasarkan pendapat para ahli diatas penulis menyimpulkan bahwa kualitas pelayanan adalah kegiatan yang dilakukan untuk memenuhi kebutuhan dan keinginan konsumen yang bertujuan untuk memberikan manfaat dan kepuasan kepada pelanggan

Menurut Gunara dan Hardiono (2006: 77), pentingnya memberikan pelayanan yang berkualitas disebabkan pelayanan (service) tidak hanya sebatas mengantarkan atau melayani. Service berarti mengerti, memahami dan merasakan sehingga penyampaiannya pun akan mengenai heart share pelanggan dan pada akhirnya memperkokoh posisi dalam mind share pelanggan. Dengan adanya heart share dan mind share yang tertanam, loyalitas seorang pelanggan pada produk atau usaha perusahaan tidak akan diragukan.

Menurut Kotler (2011: 56), dalam model kualitas jasa bahwa pengharapan pelanggan dibentuk berdasarkan 4 hal yaitu:

a. Komunikasi dari mulut ke mulut (word of mouth),

b. Kebutuhan pribadi pelanggan.

c. Pengalaman masa lalu.

d. Iklan atau promosi yang disampaikan perusahaan jasa.

\section{Indikator Kualitas Pelayanan}

Menurut Kotler (2011: 103-105), untuk mengukur kualitas pelayanan terdapat 5 indikator yaitu :

a. Tangibles atau bukti fisik, yaitu kemampuan suatu perusahaan dalam menunjukkan eksistensinya pada pihak eksternal. Penampilan dan kemampuan sarana dan prasarana fisik perusahaan dan keadaan lingkungan sekitarnya adalah bukti nyata dari layanan yang diberikan oleh pemberi jasa, ini meliputi fasilitas fisik (gedung, gudang, fasilitas fisik dan lainnya), teknologi (peralatan dan perlengkapan yang dipergunakan) serta penampilan pegawainya. 
b. Reliability atau keandalan, yaitu kemampuan perusahaan untuk memberikan layanan sesuai yang dijanjikan secara akurat dan terpercaya. Harus sesuai dengan harapan pelanggan, berarti kinerja yang tepat waktu, layanan tanpa kesalahan, sikap simpatik dan dengan akurasi tinggi.

c. Responsiveness atau ketanggapan, yaitu suatu kemauan untuk membantu dan memberikan layanan yang cepat (responsive) dan tepat kepada pelanggan. dengan yang menyampaikan informasi yang jelas. Membiarkan pelanggan menunggu tanpa alasan yang jelas, menyebabkan kualitas Pelayanan yang negative dalam kualitas jasa.

d. Assurance atau jaminan kepastian yaitu pengetahuan, kesopan santunan dan kemampuan para pegawai perusahaan untuk menumbuhkan rasa percaya pelanggan kepada perusahaan. Terdiri atas komponen komunikasi, kredibilitas, keamanan, kompetensi dan sopan santun.

e. Empathy yaitu memberikan perhatian, tulus dan bersifat individual atau pribadi kepada pelanggan dengan berupaya memahami keinginan pelanggan, dimana suatu perusahaan diharapkan memiliki suatu pengertian dan pengetahuan tentang pelanggan, memahami kebutuhan pelanggan secara spesifik serta memiliki waktu pengoprasian yang nyaman bagi pelanggan.

\section{Kepuasan Pelanggan}

Kepuasan pelanggan adalah perbandingan antara harapan dan kinerja/hasil yang dirasakan pelanggan. Harapan pelanggan dibentuk dan didasarkan oleh beberapa faktor, di antaranya pengalaman dimasa lampau, opini teman dan kerabat serta informasi dan janji-janji perusahaan.

Menurut Tjiptono (2011: 2010), realisasi kepuasan pelanggan melalui perencanaan, pengimplementasian dan pengendalian progam khusus berpotensimemberikan beberapa manfaat pokok, diantaranya sebagai berikut:

a. Reaksi terhadap produsen berbiaya rendah

Fokus pada kepuasan pelanggan merupakan upaya mempertahankan pelanggan dalam rangka menghadapi para produsen berbiaya rendah.

b. Manfaat ekonomis retensi pelanggan versus perpetual prospecting

Biaya untuk mempertahankan pelanggan lebih murah dari pada biaya mencari pelanggan baru. Ini karena komponen biaya mencari pelanggan baru meliputi sejumlah hal.

c. Nilai kumulatif dari relasi berkelanjutan

Upaya mempertahankan loyalitas pelanggan terhadap produk dan jasa perusahaan selama periode waktu yang lama bisa menghasilkan anuitas yang jauh lebih besar daripada pembelian individu.

d. Daya persuasif (word of mouth)

Dalam banyak industri (terutama sektor jasa), pendapat/opini positif dari teman dan keluarga jauh lebih persuasif dan kredibel daripada iklan

e. Reduksi sensitifitas harga

Pelanggan yang puas dan loyal terhadap sebuah perusahaan cenderung lebih jarang menawar harga untuk setiap pembelian individunya.

f. Kepuasan pelanggan sebagai indikator kesuksesan bisnis di masadepan

Pada hakikatnya kepuasan pelanggan merupakan strategi jangka panjang, karena dibutuhkan waktu cukup lama sebelum bisa membangun dan mendapatkan reputasi atas layanan prima.

Menurut Kotler dan Keller (2012: 150), kunci untuk mempertahankan pelanggan adalah

kepuasan pelanggan. Pelanggan yang sangat puas akan melakukan tindakan:

a. Tetap setia lebih lama

b. Membeli lebih banyak ketika perusahaan memperkenalkan produk baru dan memperbaharui produk-produk yangada.

c. Membicarakan hal-hal yang baik tentang perusahaan danproduk-produknya.

d. Memberi perhatian yang lebih sedikit kepada merek-merek dan iklan-iklanpesaing serta kurang peka terhadapharga.

e. Menawarkan gagasan jasa atau produk kepadaperusahaan.

f. Biaya untuk pelayanannya lebih kecil dibandingkan biaya pelayanan pelangganbaru karena transaksi yang sudahrutin.

Menurut Zeithaml dan Bitner (2009:75), definisi kepuasan adalah respon atau tanggapan konsumen mengenai pemenuhan kebutuhan. Kepuasan merupakan penilaian mengenai ciri atau 
keistimewaan produk atau jasa, atau produk itu sendiri, yang menyediakan tingkat kesenangan konsumen berkaitan dengan pemenuhan kebutuhan konsumsi konsumen.

Menurut Alma (2010: 238), kepuasan pelanggan adalah tingkat perasaan pelanggan setelah membandingkan dengan harapannya. Menurut Wilkie dalam Tjiptono (2011: 24), kepuasan didefinisikan sebagai suatu tanggapan emosional pada evaluasi terhadap pengalaman pelanggan suatu produk atau jasa. Kepuasan pelanggan merupakan evaluasi pembeli dimana alternatif yang di pilih sekurang-kurangnya sama atau melampaui harapan pelanggan, sedangkan ketidakpuasan timbul apabila hasil (outcome) tidak memenuhi harapan.

Menurut Lupyoadi dan Hamdani (2011: 127), faktor-faktor yang mempengaruhi kepuasan konsumen dalam menentukan kepuasan konsumen ada lima faktor yang harus diperhatikan oleh perusahaan yaitu :

a. Kualitas produk, yaitu pelanggan akan merasa puas bila hasil mereka menunjukkan bahwa produk yang mereka gunakan berkualitas.

b. Kualitas pelayanan atau jasa, yaitu pelanggan akan merasa puas bila mereka mendapatkan pelayanan yang baik atau sesuai dengan yang diharapkan.

c. Emosi, yaitu pelanggan akan merasa bangga dan mendapatkan keyakinan bahwa orang lain akan kagum terhadap dia bila menggunakan produk dengan merek tertentu yang cenderung mempunyai tingkat kepuasan yang lebih tinggi. Kepuasan yang diperoleh bukan karena kualitas dari produk tetapi sosial atau self esteem yang membuat pelanggan merasa puas terhadap merek tertentu.

d. Harga, yaitu produk yang mempunyai kualitas yang sama tetapi menetapkan harga yang relatif murah akan memberikan nilai yang lebih tinggi kepada pelanggan.

e. Biaya, yaitu pelanggan yang tidak perlu mengeluarkan biaya tambahan atau tidak perlu membuang waktu untuk mendapatkan suatu produk atau jasa cenderung puas terhadap produk atau jasa tersebut.

\section{Indikator Kepuasan Pelanggan}

Menurut Kotler (2011: 60), pengukuran kepuasan dapat diukur dengan beberapa cara, kepuasan dapat diukur dengan menanyakan secara langsung kepuasan pelanggan dengan menggunakan skala. Responden dapat diminta untuk memberikan peringkat seberapa besar harapan terhadap atribut tertentu dan seberapa besar yang dialaminya. Adapun metode lain yang dapat digunakan seperti dengan meminta responden membuat daftar masalah yang dihadapi dan membuat daftar yang disarankan untuk perbaikan (problem analysis).

Menurut Kotler (2011: 74), dalam menilai kepuasan pelanggan dapat dilakukan dengan 3 cara yaitu :

a. Kualitas yang diberikan sesuai dengan yang dijanjikan.

b. Pelayanan yang baik dan memberikan kepuasan bagi pelanggan.

c. Kepuasan bagi setiap pelanggan

\section{Faktor-Faktor Yang Mempengaruhi Pelayanan Pelanggan}

Menurut Moenir (2010: 41),kaktor-faktor pendukung pelayanan adalah :

a. Faktor kesadaran

Adanya kesadaran dapat membawa seseorang kepada keikhlasan dan kesungguhan dalam menjalankan atau melaksanakan suatu kehendak. Kehendak dalam lingkungan organisasi kerja tertuang dalam bentuk tugas, baik tertulis maupun tidak tertulis, mengikat semua orang dalam organisasi kerja. Karena itu dengan adanya kesadaran pada pegawai atau petugas, diharapkan dapat melaksanakan tugas dengan penuh keikhlasan, kesungguhan dan disiplin. Kelebihan dan tingkah laku orang lain jika disadari lalu dikembangkan dapat menjadi faktor pendorong bagi kemajuan dan keberhasilan.

b. Faktor aturan

Aturan adalah perangkat penting dalam segala tindakan dan perbuatan orang. Makin maju dan majemuk suatu masyarakat makin besar peranan aturan dan dapat dikatakan orang tidak dapat hidup layak dan tenang tanpa aturan. Oleh karena itu aturan demikian 
besar dalam hidup masyarakat maka dengan sendirinya aturan harus dibuat, dipatuhi dan diawasi sehingga dapat mencapai sasaran sesuai dengan maksudnya. Dalam organisasi kerja dibuat oleh manajemen sebagai pihak yang berwenang mengatur segala sesuatu yang ada di organisasi kerja tersebut. Oleh karena setiap orang pada akhirnya menyangkut langsung atau tidak langsung kepada orang, maka masalah manusia serta sifat kemanusiaannya harus menjadi pertimbangan utama. Pertimbangan harus diarahkan kepada sebagai subyek aturan, yaitu mereka yang akan dikenai aturan itu.

c. Faktor organisasi

Organisasi pada dasarnya tidak berbeda dengan organisasi pada umunya, namun ada perbedaan sedikit dalam penerapannya karena sasaran pelayanan ditujukan secara khusus, kepada manusia yang mempunyai dan kehendak multikompleks, kepada manusia yang mempunyai dan kehendak multikompleks. Oleh karena itu organisasi yang dimaksud disini tidak semata-mata dalam perwujudan susunan organisasi, melainkan lebih banyak pada pengaturan dan mekanisme kerjanya yang harus mampu menghasilkan pelayanan yang memadai.

d. Faktor pendapatan

Pendapatan adalah seluruh penerimaan seseorang sebagai imbalan atas tenaga dana serta pikiran yang telah dicurahkan untuk orang lain atau badan/organisasi, baik dalam bentuk uang, maupun fasilitas, dalam jangka waktu tertentu. Pada dasarnya pendapatan harus dapat memenuhi kebutuhan hidup baik untuk dirinya maupun keluarganya.

e. Faktor kemampuan dan keterampilan

Kemampuan yang dimaksud disini adalah keadaan yang ditujukan pada sifat atau keadaan seseorang dalam melaksanakan tugas atau pekerjaan atas ketentuan-ketentuan yang ada. Istilah yang "kecakapan" selanjutnya keterampilan adalah kemampuan melaksanakan tugas atau pekerjaan dengan menggunakan anggota badan dan pengetahuan kerja yang tersedia. Dengan pengertian ini dapat dijelaskan bahwa keterampilan lebih banyak menggunakan unsur anggota badan dari pada unsur lain.

f. Faktor sarana pelayanan

Sarana pelayanan yang dimaksud disini adalah segala jenis pelayanan, perlengkapan kerja dan fasilitas lain yang berfungsi sebagai alat utama atau pembantu dalam pelaksanaan pekerjaan dan juga berfungsi sosial dalam rangka kepentingan orang-orang yang sedang berhubungan dengan organisasi kerja itu.

\section{METODE PENELITIAN}

Data

Menurut Dachlan (2014: 18), dilihat dari sumbernya data yang digunakan dalam penelitian ini adalah :

a. Data Primer

Data primer adalah data yang diperoleh penelitian secara langsung dari sumbernya. Data yang dikumpul melalui kuesioner, wawancara, observasi langsung di lapangan, dan melalui eksperimen adalah contoh data primer.

b. Data Sekunder

Data sekunder adalah data yang diperoleh peneliti tidak secara langsung dari sumbernya melainkan telah dikumpulkan oleh pihak lain seperti profil perusahaan, data pelanggan, jumlah karyawan dan lain-lain.

\section{Variabel Penelitian}

Menurut Sugiyono (2010: 145), variabel penelitian adalah hal yang berbentuk apa saja yang ditetapkan oleh peneliti untuk dipelajari sehingga diperoleh informasi tentang hal tersebut. Ada 2 (dua) variabel utama yang menjadi fokus perhatian penelitian ini yaitu variabel independen/bebas merupakan variabel yang mempengaruhi atau yang menjadi sebab perubahannya atau timbulnya variabel dependen/terikat. Variabel independen dalam 
penelitian ini adalah kualitas pelayanan (X). Variabel kualitas pelayanan diukur dengan menggunakan indikator Tangible, Realibility, Responsiveness, Assurance dan Emphaty sedangkan variabel terikat adalah variabel yang dipengaruhi atau yang menjadi akibat, karena adanya variabel bebas. Variabel dependen dalam penelitian ini adalah kepuasan pelanggan (Y). Variabel kepuasan pelanggan diukur menggunakan indikator Kualitas diberikan, Pelayanan yang baik dan Kepuasan bagi setiap pelanggan.

Populasi, Sampel dan Teknik Pengambilan Sampel

Menurut Malhotra (2009: 364), populasi adalah gabungan seluruh elemen yang memiliki serangkaiaan karekteristik serupa, yang mencakup semesta untuk kepentingan masalah riset pemasaran. Adapun populasi penelitan ini adalah seluruh pelanggan listrik Prabayar PT. PLN (Persero) Rayon Sekayu di Kecamatan Sekayu periode yang berjumlah 19.145 pelanggan, jumlah tersebut dapat dilihat pada tabel dibawah ini :

Tabel 1. Daftar Jumlah Pelanggan Listrik Prabayar di Kecamatan Sekayu

\begin{tabular}{|c|c|c|}
\hline No. & \multicolumn{1}{|c|}{ Jenis Golongan } & Jumlah \\
\hline 1 & Rumah Tangga Subsidi & 2.111 \\
\hline 2 & Rumah Tangga Tidak Subsidi & 17.034 \\
\hline \multicolumn{2}{|c|}{ Jumlah Tolal } & 19.145 \\
\hline
\end{tabular}

Sumber : $\underline{\text { www.eis.pln.co.id }}$

Menurut Sugiyono (2010: 116), Sampel merupakan sebagian dari jumlah dan karikteritik populasi. Sampel yang baik adalah sampel yang refresentatif mewakili populasi. Dalam penentuan jumlah sampel dari populasi penulis menggunakan rumus Slovin. Untuk menghitung ukuran sampel dari populasi yang diketahui jumlahnya dengan rumus :

$$
\begin{aligned}
& n=\frac{N}{1+N e^{2}} \\
& \text { Keterangan : } \\
& \mathrm{n} \quad=\text { Jumlah Sampel } \\
& \mathrm{N} \quad=\text { Jumlah Populasi } \\
& \mathrm{e} \quad=\text { Taraf Kesalahan }
\end{aligned}
$$

Besarnya sampel untuk menaksirkan rata-rata populasi dapat dicari dengan ditetapkannya taraf kesalahan $10 \%$ maka jumlah sampel penelitian ditentukan sbb:

$$
\begin{aligned}
& n=\frac{N}{1+N e^{2}} \\
& n=\frac{19.145}{1+19.145(0,1)^{2}} \\
& n=99,48 \text { atau } 99
\end{aligned}
$$

Berdasarkan jumlah sampel diatas, maka penyebaran sampelnya adalah : karena responden penelitian tersebar dibeberapa jenis golongan yang berbeda, terdiri Rumah Tangga Subsidi dan Rumah Tangga Tidak Subsidi.

$$
\begin{aligned}
& i=\frac{i}{N} x n \\
& \text { Keterangan : } \\
& n_{i}=\text { ukuran sampel setiap golongan } \\
& N i=\text { ukuran populasi setiap golongan } \\
& \mathrm{N}=\text { jumlah populasi } \\
& n=\text { jumlah sampel }
\end{aligned}
$$

Tabel 2. Persentase Sampel Pelanggan Prabayar

\begin{tabular}{|c|l|c|c|}
\hline No. & Jenis Golongan & Jumlah & Persentase Sampel \\
\hline 1 & Rumah Tangga Subsidi & 2.111 & $99 / 19.145 \times 2.111=11$ \\
\hline
\end{tabular}




\begin{tabular}{|c|l|c|c|}
\hline 2 & Rumah Tangga Tidak Subsidi & 17.034 & $99 / 19.145 \times 17.034=88$ \\
\hline \multicolumn{2}{|c|}{ Jumlah Tolal } & 19.145 & 99 \\
\hline
\end{tabular}

Sumber : www.eis.pln.co.id

Adapun pengambilan sampel dalam penelitian ini dilaksanakan dengan menggunakan metode non-probability sampling (pengambilan sampel secara tidak acak) dengan menggunakan teknik pengambilan sampel purposive sampling, dimana sampel dipilih berdasarkan karekteristik. Teknik ini dipilih karena populasi dan sampel yang diambil memiliki karekteristik tertentu. Karekteristik tersebut adalah :

a. Pelanggan Listrik Prabayar

b. Yang ada di Kelurahan Kayuara, Kelurahan Serasan Jaya, Kelurahan Soak Baru dan Kelurahan Balai Agung

Teknik Pengelolaan Data

Adapun teknik pengelolaan data dalam penelitian ini penulis menggunakan program SPSS versi 20. Menurut Priyatno (2011: 13), SPSS adalah program atau sofware olah yang digunakan untuk olah data statistik. Adapun tahap-tahap analisis data yang digunakan adalah sebagai berikut :

\section{Uji Validitas}

Menurut Priyatno (2011: 16), uji validitas digunakan untuk mengukur sah atau valid tidaknya suatu kuesioner. Suatu kuesioner dikatakan valid jika pertanyaan pada kuesioner mampu untuk mengungkapkan sesuatu yang akan diukur oleh kuesioner tersebut, dalam hal ini digunakan beberapa butir pertanyaan yang dapat secara tepat mengungkapkan variabel yang diukur tersebut. Untuk mengukur tingkat validitas dapat dilakukan dengan cara mengkorelasikan antara skor butir pertanyaan dengan total skor konstruk atau variabel. Pengujian menggunakan uji dua sisi dengan taraf signifikansi 0,05 . Kriteria pengujian adalah sebagai berikut :

a. Jika $r$ hitung $\geq r$ tabel (uji 2 sisi dengan sig 0,05 ) maka instrumen atau item-item pertanyaan berkolerasi signifikan terhadap skor total (dinyatakan valid).

b. Jika $r$ hitung $\leq \mathrm{r}$ tabel (uji 2 sisi dengan sig 0,05 ) maka instrumen atau item-item pertanyaan tidak berkolerasi signifikan terhadap skor total (dinyatakan tidak valid).

Menurut Priyatno (2011: 17), uji validitas dilakuan dengan membandingkan nilai $r$ hitung dengan $r$ tabel untuk tingkat signifikansi 5 persen dari degree of freedom $(\mathrm{df})=\mathrm{n}-2$, dalam hal ini $\mathrm{n}$ adalah jumlah sampel. Jika $\mathrm{r}$ hitung $>\mathrm{r}$ tabel maka pertanyaan atau indikator tersebut dinyatakan valid, demikian sebaliknya bila $\mathrm{r}$ hitung $<\mathrm{r}$ tabel maka pertanyaan atauindikator tersebut dinyatakan tidak valid

\section{Uji Reliabilitas}

Menurut Priyatno (2011: 25), uji reliabilitas merupakan alat untuk mengukur suatu kuesioner yang merupakan indikator dari variabel atau konstruk. Suatu kuesioner dikatakan reliable atau handal jika jawaban seseorang terhadap pernyataan adalah konsisten atau stabil dari waktu ke waktu. Pengukuran reliabilitas dilakukan dengan cara one shot atau pengukuran sekali saja dengan alat bantu SPSS uji statistik Cronbach Alpha ( $\alpha)$. Untuk pengambilan keputusan uji reabilitas bisa menggunakan batasan 0,60, menurut Sekaran dalam Priyatno (2011: 25), reabilitas kurang dari 0.60 adalah kurang baik, sedangkan 0.7 dapat diterima dan diatas 0.8 adalah baik.

\section{Analisis Regresi Linier Sederhana}

Analisis ini digunakan untuk mengetahui seberapa besar pengaruh variabel bebas kualitas pelayanan $(\mathrm{X})$ terhadap variabel terikatnya kepuasan pelanggan (Y). Menurut Priyatno (2011: 65), persamaan regresi linier sederhana adalah sebagai berikut :

$$
\mathbf{Y}=\mathbf{a}+\mathbf{b X}+\mathbf{e}
$$

Keterangan :

$\mathrm{Y}=$ Variabel dependen (kepuasan pelanggan) 


\section{Uji Korelasi}

$\mathrm{X}=$ Variabel independen (kualitas pelayanan)

$\mathrm{a}=$ Konstanta

$\mathrm{b}=$ Koefisien garis regresi

$\mathrm{e}=$ Error

Menurut Priyatno (2011: 99), analisis korelasi sederhana (Bivariate Correlation) digunakan untuk mengetahui keeratan hubungan antara dua variabel dan untuk mengetahui arah hubungan yang terjadi. Koefisien korelasi sederhana menunjukkan seberapa besar hubungan yang terjadi antara dua variabel. Pada bab ini akan dibahas analisis korelasi sederhana dengan metode Pearson atau sering disebut Product Moment Pearson. Nilai korelasi (r) berkisar antara 0 sampai 1, nilai semakin mendekati 0 atau 1 berarti hubungan antara dua variabel semakin kuat, sebaliknya nilai mendekati 0 berarti hubungan antara dua variabel semakin lemah. Nilai positif menunjukkan hubungan searah sistem pemberian kualitas pelayanan baik maka kepuasan pelanggan akan meningkat) dan nilai negatif menunjukkan hubungan terbalik (kualitas pelayanan tidak bagus atau buruk maka kepuasan pelanggan pegawai akan menurun). Pedoman untuk memberikan interprestasi koefisien korelasi adalah :

a. Jika korelasi 0,0 sampai 0,199 hubungannya sangat rendah.

b. Jika korelasi 0,20 sampai 0,399 hubungannya rendah.

c. Jika korelasi 0,40 sampai 0,599 hubungannya sedang.

d. Jika korelasi 0,60 sampai 0,799 hubungannya kuat.

e. Jika korelasi 0,80 sampai 1,000 sangat kuat.

\section{Uji Hipotesis (Uji t)}

Uji t digunakan untuk menguji signifikansi hubungan antara variabel $\mathrm{X}$ dan $\mathrm{Y}$, apakah variabel X (kualitas pelayanan) benar-benar berpengaruh terhadap variabel Y(kepuasan pelanggan) secara terpisah atau parsial Priyatno (2011:, 61). Hipotesis yang digunakan dalam pengujian ini adalah :

Ho: Tidak ada pengaruh kualitas pelayanan terhadap kepuasan pelanggan listrik prabayar pada PT. PLN (Persero) Rayon Sekayu

$\mathrm{Ha}$ : Ada pengaruh kualitas pelayanan terhadap kepuasan pelanggan listrik prabayar pada PT. PLN (Persero) Rayon Sekayu

Dasar pengambilan keputusan Priyatno (2011: 65). adalah dengan menggunakan angka probabilitas signifikansi yaitu :

a. Apabila angka probabilitas signifikansi $>0,05$, maka Ho diterima dan Ha ditolak. Artinya tidak ada Pengaruh Kualitas pelayanan Terhadap Kepuasan pelanggan Pegawai Harian Lepas Pada PT. PLN (Persero) Rayon Sekayu.

b. Apabila angka probabilitas signifikansi $<0,05$, maka Ho ditolak dan Ha diterima. Artinya ada Pengaruh Kualitas pelayanan Terhadap Kepuasan pelanggan Pegawai Harian Lepas Pada PT. PLN (Persero) Rayon Sekayu.

Untuk menguji apakah hipotesis yang diajukan diterima atau ditolak digunakan statistik $\mathrm{t}$ (uji satu sisi). Adapun kriteria pengujian sebagai berikut :

a. $\quad$ Jika $-\mathrm{t}$ tabel $\leq \mathrm{t}$ hitung $\leq+\mathrm{t}$ tabel maka Ho diterima dan Ha ditolak.

b. Jika $t$ hitung $\leq-t$ tabel atau $t$ hitung $>+t$ tabel maka Ho ditolak dan Ha diterima.

\section{HASIL DAN PEMBAHASAN}

\section{Hasil Olah Data}

\section{Pengujian Validitas dan Reliability}

Uji validitas digunakan untuk menguji sejauh mana ketepatan alat pengukur dapat mengungkapkan konsep gejala atau kejadian yang diukur. Item kuesioner dinyatakan valid apabila nilai $\mathrm{r}$ hitung $>\mathrm{r}$ tabel $(\mathrm{n}-2)$. Pengujian validitas selengkapnya dapat di lihat pada tabel berikut ini :

Tabel 3. Hasil Pengujian Validitas 


\begin{tabular}{|c|c|c|c|c|}
\hline No. & Variabel/Indikator & r hitung & $r$ table & Keterangan \\
\hline & \multicolumn{4}{|c|}{ Kualitas Pelayanan (X) } \\
\hline 1 & item 1 & 0,455 & 0,1975 & Valid \\
\hline 2 & item2 & 0,266 & 0,1975 & Valid \\
\hline 3 & item3 & 0,304 & 0,1975 & Valid \\
\hline 4 & item4 & 0,336 & 0,1975 & Valid \\
\hline 5 & item5 & 0,322 & 0,1975 & Valid \\
\hline 6 & item6 & 0,472 & 0,1975 & Valid \\
\hline 7 & item7 & 0,351 & 0,1975 & Valid \\
\hline 8 & item8 & 0,239 & 0,1975 & Valid \\
\hline 9 & item9 & 0,303 & 0,1975 & Valid \\
\hline \multirow[t]{2}{*}{10} & item 10 & 0,310 & 0,1975 & Valid \\
\hline & \multicolumn{4}{|c|}{ Kepuasan Pelanggan (Y) } \\
\hline 1 & item 1 & 0,447 & 0,1975 & Valid \\
\hline 2 & item2 & 0,234 & 0,1975 & Valid \\
\hline 3 & item 3 & 0,584 & 0,1975 & Valid \\
\hline 4 & item4 & 0,388 & 0,1975 & Valid \\
\hline 5 & item5 & 0,461 & 0,1975 & Valid \\
\hline 6 & item6 & 0,404 & 0,1975 & Valid \\
\hline 7 & item7 & 0,308 & 0,1975 & Valid \\
\hline 8 & item 8 & 0,373 & 0,1975 & Valid \\
\hline 9 & item9 & 0,335 & 0,1975 & Valid \\
\hline 10 & item10 & 0,456 & 0,1975 & Valid \\
\hline
\end{tabular}

Sumber : Data primer (diolah), tahun 2019

Tabel diatas terlihat bahwa korelasi antara masing-masing indikator terhadap total skor konstruk dari setiap variabel menunjukkan hasil yang signifikan, dan menunjukkan bahwa $r$ hitung (Corrected Item-Total Correlation) $>\mathrm{r}$ tabel $(0,1975)$ Sehingga dapat disimpulkan bahwa semua item pernyataan dinyatakan valid.

Tabel 4. Hasil Pengujian Reliabilitas

\begin{tabular}{|c|c|c|c|}
\hline No & Variabel & Alpha & Keterangan \\
\hline 1. & Kualitas Pelayanan $(\mathrm{X})$ & 0,675 & Reliable \\
\hline 2. & Kepuasan Pelanggan $(\mathrm{Y})$ & 0,652 & Reliable \\
\hline
\end{tabular}

Sumber : Data primer (diolah), tahun 2019

Berdasarkan tabel diatas terlihat bahwa uji reliabilitas dilakukan terhadap item Pernyataan yang dinyatakan valid. Suatu variabel dikatakan reliabel atau handal jika jawaban terhadap pernyataan selalu konsisten. Jadi hasil koefisien reliabilitas instrument kualitas pelayanan (X) adalah sebesar Cronbach's Alpha $=0,675$, dan instrument kepuasan (Y) pelanggan adalah sebesar Cronbach's Alpha $=0,652$. Berdasarkan hasil nilai perhitungan dari SPSS tersebut ternyata memiliki nilai "Alpha Cronbach" lebih besar dari 0,60, yang berarti kedua instrumen dinyatakan reliable atau memenuhi persyaratan.

\section{Hasil Analisis Regresi Linear Sederhana}

Analisis ini digunakan untuk mengetahui seberapa besar pengaruh variabel Independen yaitu kualitas pelayanan (X) terhadap variabel dependen yaitu kepuasan pelanggan (Y). Dari analisis sebelumnya telah terbukti bahwa model persamaan yang diajukan dalam penelitian ini telah memenuhi persyaratan sehingga model persamaan dalam penelitian ini sudah dianggap baik. Analisis regresi digunakan untuk menguji hipotesis tentang pengaruh variabel independen terhadap variabel dependen berdasarkan estimasi regresi linear sederhana dengan program SPSS diperoleh hasil seperti tabel dibawah ini: 
Tabel 5. Hasil Analisis Regresi Linear Sederhana

\begin{tabular}{|l|l|r|r|r|r|r|}
\hline \multicolumn{7}{|c|}{ Coefficients $^{\mathbf{a}}$} \\
\hline \multirow{2}{*}{ Model } & \multicolumn{2}{|c|}{$\begin{array}{c}\text { Unstandardized } \\
\text { Coefficients }\end{array}$} & $\begin{array}{c}\text { Standardized } \\
\text { Coefficients }\end{array}$ & \multirow{2}{*}{$\mathrm{t}$} & \multirow{2}{*}{ Sig. } \\
\cline { 2 - 7 } \multicolumn{2}{|l|}{} & \multicolumn{1}{c|}{ B } & Std. Error & Beta & & \\
\hline \multirow{2}{*}{1} & (Constant) & 25,456 & 4,101 & & 6,207 &, 000 \\
\cline { 2 - 7 } & kualitas.pelayanan_X &, 274 &, 118 &, 230 & 2,332 &, 022 \\
\hline
\end{tabular}

a. Dependent Variable: kepuasan.pelanggan_Y

Sumber : Data primer (diolah), tahun 2019

Berdasarkan tabel diatas dapat diketahui persamaan regresi yang terbentuk adalah : $\mathrm{Y}=25,456+0,274 \mathrm{X}$

Dari persamaan tersebut dapat dijelaskan bahwa :

a.

Nilai Konstanta sebesar 25,456 menunjukkan bahwa jika kualitas pelayanan dianggap tidak ada (nol) maka kepuasan pelanggan sebesar 25,456.

b. Koefisien regresi variabel kualitas pelayanan (X) menunjukkan pengaruh positif sebesar 0,274 terhadap kepuasan pelanggan (Y). Koefisien regresi bernilai positif apabila nilai variabel kualitas pelayanan $(\mathrm{X})$ bertambah maka variabel kepuasan pelanggan (Y) bertambah.

\section{Analisis Korelasi}

Analisis korelasi (r) digunakan untuk mengukur tinggi rendahnya derajat hubungan antara variabel yang diteliti. Tinggi rendahnya derajat keeratan tersebut dapat di lihat dari koefisien korelasinya. Adapun untuk hasil perhitungan korelasi dalam bab ini dapat di lihat dari tabel dibawah ini :

Tabel 6. Hasil Uji Korelasi

\begin{tabular}{|l|r|r|r|c|}
\hline \multicolumn{5}{|c|}{ Model Summary } \\
\hline Model & R & R Square & $\begin{array}{c}\text { Adjusted R } \\
\text { Square }\end{array}$ & $\begin{array}{c}\text { Std. Error of the } \\
\text { Estimate }\end{array}$ \\
\hline 1 &, $230^{\mathrm{a}}$ &, 053 &, 043 & 4,911 \\
\hline \multicolumn{2}{|r|}{ a. Predictors: (Constant), kualitas.pelayanan_X } \\
\hline
\end{tabular}

Sumber : Data primer (diolah), tahun 2019

Berdasarkan tabel diatas maka didapatkan nilai korelasi variabel Kepuasan pelanggan (r) sebesar 0,230. Dari penafsiran terhadap koefisien korelasi tersebut dapat diketahui bahwa terjadi hubungan positif yang rendah Sedangkan nilai $\mathrm{R}^{2}$ (R Sequare) sebesar 0,053 menunjukkan bahwa variabel kualitas pelayanan mempengaruhi kepuasan pelanggan sebesar $5,3 \%$, sedangkan sisanya $94,7 \%$ dipengaruhi oleh variabel lain yang tidak diteliti dalam penelitian ini.

\section{Uji Hipotesis (Uji t)}

Adapun pegujian hipotesis secaradalam dilihat pada tabel dibawah ini :

Tabel 7.Uji Hipotesis (Uji t)

\begin{tabular}{|c|c|c|c|c|c|c|}
\hline \multicolumn{7}{|c|}{ Coefficients $^{\mathrm{a}}$} \\
\hline \multirow{2}{*}{\multicolumn{2}{|c|}{ Model }} & \multicolumn{2}{|c|}{$\begin{array}{c}\text { Unstandardized } \\
\text { Coefficients }\end{array}$} & $\begin{array}{l}\text { Standardized } \\
\text { Coefficients }\end{array}$ & \multirow[t]{2}{*}{$\mathrm{t}$} & \multirow[t]{2}{*}{ Sig. } \\
\hline & & $\mathrm{B}$ & Std. Error & Beta & & \\
\hline \multirow{2}{*}{1} & (Constant) & 25,456 & 4,101 & & 6,207 &, 000 \\
\hline & kualitas.pelayanan_X & 274 &, 118 & 230 & 2,332 & ,022 \\
\hline
\end{tabular}

Sumber : Data primer (diolah), tahun 2019 
Berdasarkan tabel diatas dapat diketahui bahwa nilai $t_{\text {hitung }}$ adalah 2,332 sedangkan $t_{\text {tabel }}$ 1,984, oleh karena nilai $t_{\text {hitung }}>t_{\text {tabel }}$ yaitu 2,332> 1,984, maka $H_{O}$ ditolak dan $H_{a}$ diterima. Artinya bahwa ada pengaruh kualitas pelayanan terhadap kepuasan pelanggan listrik prabayar pada PT. PLN (Persero) Rayon Sekayu.

Implementasi Hasil Penelitian

Berdasarkan hasil uji hipotesis (uji t) didapakan nilai $t_{\text {hitung }}$ adalah 2,332 sedangkan $t_{\text {tabel }} 1,984$, oleh karena nilai $t_{\text {hitung }}>t_{\text {tabel }}$ yaitu 2,332> 1,984, maka $H_{O}$ ditolak dan $H_{a}$ diterima. Artinya bahwa ada pengaruh kualitas pelayanan terhadap kepuasan pelanggan listrik prabayar pada PT. PLN (Persero) Rayon Sekayu.

Hasil penelitian ini mendukung penelitian terdahu yang dilakukan oleh Agus Rizkia 2017, judul penelitian Pengaruh kualitas pelayanan terhadap kepuasan pelanggan pada Bengkel Motor JM Sekayu Kabupaten Musi Banyuasin, Berdasarkan hasill uji hipotesis diketahui bahwa hasil pengujian uji $t$ menunjukkan bahwa nilai $t_{\text {hitung }}$ adalah 2,436 sedangkan $t_{\text {tabel }} 1,984$, oleh karena nilai $t_{\text {hitung }}>t_{\text {tabel }}$ yaitu 2,436 $>1,984$, maka $\mathrm{H}_{O}$ ditolak dan menerima $\mathrm{H}_{\mathrm{a}}$. Artinya bahwa kualitas pelayanan berpengaruh terhadap kepuasan pelanggan pada bengkel Motor JM Sekayu.

\section{Kesimpulan}

Dari hasil pembahasan pada bab sebelumnya dan perhitungan statistik, maka Penulis dapat menyimpulkan bahwa :

a. Hasil uji korelasi didapatkan nilai korelasi variabel Kepuasan pelanggan sebesar 0,230. Dari penafsiran terhadap koefisien korelasi tersebut dapat diketahui bahwa terjadi hubungan positif yang rendah. Sedangkan nilai $\mathrm{R}^{2}$ (R Sequare) sebesar 0,053 menunjukkan bahwa variabel kualitas pelayanan mempengaruhi kepuasan pelanggan sebesar 5,3\%, sedangkan sisanya $94,7 \%$ dipengaruhi oleh variabel lain yang tidak diteliti dalam penelitian ini.

b. Hasil uji hipotesis diketahui bahwa nilai $t_{\text {hitung }}$ adalah 2,332 sedangkan $t_{\text {tabel }} 1,984$, oleh karena nilai $\quad t_{\text {hitung }}>t_{\text {tabel }}$ yaitu 2,332> 1,984, maka $\mathrm{H}_{\mathrm{O}}$ ditolak dan $\mathrm{H}_{\mathrm{a}}$ diterima. Artinya bahwa ada pengaruh kualitas pelayanan terhadap kepuasan pelanggan listrik prabayar pada PT. PLN (Persero) Rayon Sekayu.

c. Persamaan Regresinya adalah $\mathrm{Y}=25,456+0,274 \mathrm{X}$

\section{Daftar Pustaka}

Alma, Buchori. 2010. Manajemen Pemasaran dan Pemasaran Jasa. Bandung : Alfabeta.

Agus Rizkia. 2017. Pengaruh kualitas pelayanan terhadap kepuasan pelanggan pada Bengkel

Motor JM Sekayu Kabupaten Musi Banyuasin. Skripsi STIER Sekayu.

Dachlan, Usman. 2014. Structural Equation Modeling. Semarang : Lentera Ilmu

Gunara, Thorik \& Hardiono. 2006. Marketing Muhammad. Bandung : Takbir Publishing House.

Kotler, Philip. 2011. Manajemen Pemasaran Analisis, Perencanaan dan Pengendalian, Jilid Dua. Jakarta : Erlangga.

Kotler, Philip dan Kevin Lane Keller. 2012. Manajemen Pemasaran. Jilid I. Edisi ke 13 Jakarta: Erlangga.

Lupiyoadi, Rambat \& A. Hamdani. 2011. Manajemen Pemasaran Jasa. Edisi Pertama. Cetakan Pertama. Jakarta : Salemba Empat.

Malhotra, Naresh K. 2009. Riset Pemasaran. Edisi Empat. Jilid I. Jakarta. PT. Indeks. Moenir. 2010. Manajmen Pelayanan Umum di Indonesia. Jakarta : Bumi Aksara. Priyatno, Dwi. 2011. Mandiri Program SPSS. Yogyakarta : Mediakom Sugiyono. 2010. Metode Penelitian. Bandung : Alfabeta.

Tjiptono, Fandy. 2011. Strategi Pemasaran. Yogyakarta : CV. Andi.

Zeithaml dan Bitner, 2009. Service Marketing :Integrating Customer Focus. 